\title{
THERMODYNAMIC STABILITY OF ACTINIDE PYROCHLORE MINERALS IN DEEP GEOLOGIC REPOSITORY ENVIRONMENTS
}

Yifeng Wang*, Huifang Xu**

"Sandia National Laboratories, 4100 National Parks Highway, Carlsbad, New Mexico 88220. E-mail: ywang@sandia.gov

** Department of Earth and Planetary Sciences, The University of New Mexico, Albuquerque, New Mexico 87131. E-mail: hfxu@unm.edu

\begin{abstract}
Crystalline phases of pyrochlore (e.g., $\mathrm{CaPuTi}_{2} \mathrm{O}_{7}, \mathrm{CaUTi}_{2} \mathrm{O}_{7}$ ) have been proposed as a durable ceramic waste form for disposal of high level radioactive wastes including surplus weapons-usable plutonium. In this paper, we use a linear free energy relationship to predict the Gibbs free energies of formation of pyrochlore phases $\left(\mathrm{CaMTi}_{2} \mathrm{O}_{7}\right)$. The $\mathrm{Pu}$-pyrochlore phase is predicted to be stable with respect to $\mathrm{PuO}_{2}, \mathrm{CaTiO}_{3}$, and $\mathrm{TiO}_{2}$ at room temperatures. Pu-pyrochlore is expected to be stable in a geologic repository where silica and carbonate components are absent or limited. We suggest that a repository in a salt formation be an ideal environment for disposal of high level, pyrochlore-based ceramic wastes. In such environment, adding $\mathrm{CaO}$ as a backfill will make pyrochlore minerals thermodynamically stable and therefore effectively prevent actinide release from these mineral phases.
\end{abstract}

\section{INTRODUCTION}

Crystalline phases of pyrochlore (e.g., $\mathrm{CaPuTi}_{2} \mathrm{O}_{7}, \mathrm{CaUTi}_{2} \mathrm{O}_{7}$ ) have been proposed as a durable ceramic waste form for disposal of high level radioactive wastes including surplus weapons-usable plutonium $[1,2]$. Pyrochlore phases typically have a derivative fluorite structure and have a stoichiometry of $\mathrm{CaMTi}_{2} \mathrm{O}_{7}$, where $\mathrm{M}$ represents tetravalent cations such as $\mathrm{Zr}, \mathrm{Hf}, \mathrm{U}, \mathrm{Pu}$ and other actinides. The existence of large polyhedra (with coordination numbers ranging from 7 to 8 ) in mineral structure allows pyrochlore phases to accommodate a wide range of radionuclides (e.g., $\mathrm{Pu}, \mathrm{U}, \mathrm{Ba}$, etc.) as well as neutron poisons (e.g., Hf, Gd) [3].

Since most of the existing work on pyrochlore minerals has been focused on fabrication, structural characterization and leaching tests, the thermodynamic data of these mineral phases are still lacking. In this paper, we will use a linear free energy relationship to predict the Gibbs free energies of formation for various pyrochlore phases. Based on the predicted Gibbs free energies, the stability of actinide pyrochlore minerals in deep geologic repository environments will be discussed.

\section{LINEAR FREE ENERGY RELATIONSHIP}

Sverjensky and Molling have developed a linear free energy relationship that correlates the Gibbs free energies of formation of an isostructural family of inorganic 


\section{DISCLAIMER}

This report was prepared as an account of work sponsored by an agency of the United States Government. Neither the United States Government nor any agency thereof, nor any of their employees, make any warranty, express or implied, or assumes any legal liability or responsibility for the accuracy, completeness, or usefulness of any information, apparatus, product, or process disclosed, or represents that its use would not infringe privately owned rights. Reference herein to any specific commercial product, process, or service by trade name, trademark, manufacturer, or otherwise does not necessarily constitute or imply its endorsement, recommendation, or favoring by the United States Government or any agency thereof. The views and opinions of authors expressed herein do not necessarily state or reflect those of the United States Government or any agency thereof. 


\section{DISCLAIMER}

Portions of this document may be illegible in electronic image products. Images are produced from the best available original document. 
solids with chemical properties of aqueous free cations [4]. This free energy relationship has been successfully applied to a wide variety of mineral phases $[4,5,6,7]$. The linear free energy relationship for an isotructural family of minerals can be expressed as $[4,5]$ :

$$
\Delta \mathrm{G}_{\mathrm{f}, \mathrm{MX}}^{0}=a_{\mathrm{MX}} \Delta \mathrm{G}_{\mathrm{n}, \mathrm{M}}^{0} \mathrm{Z}^{+}+b_{\mathrm{MX}}+\beta_{\mathrm{MX}} r_{\mathrm{M}} \mathrm{Z}^{+} .
$$

where the coefficients $a_{\mathrm{MX}}, b_{\mathrm{MX}}$, and $\beta_{\mathrm{MX}}$ characterize a particular structural family of minerals $\mathrm{MX} ; r_{\mathrm{M}} \mathrm{Z}+$ is the ionic radius of cation $\mathrm{M}^{\mathrm{Z}}$; the parameter $\Delta \mathrm{G}_{\mathrm{f}, \mathrm{MX}}^{0}$ is the standard Gibbs free energies of formation of solid $M X$; and the parameter $\Delta \mathrm{G}_{\mathrm{n}, \mathrm{M}}^{\mathrm{Z}+}$ is the standard non-solvation energy from a radius-based correction to the standard Gibbs free energy of formation of the aqueous tetravalent cation $\mathrm{M}^{4+}$ [4]. The parameter $\Delta \mathrm{G}_{\mathrm{n}, \mathrm{M}^{2+}}^{2+}$ can be calculated by:

$$
\Delta \mathrm{G}_{\mathrm{n}, \mathrm{M}^{\mathrm{Z}}}^{\mathrm{Z}}=\Delta \mathrm{G}_{\mathrm{f}, \mathrm{M}^{\mathrm{Z}}}^{0}-\Delta \mathrm{G}_{\mathrm{s}, \mathrm{M}^{\mathrm{Z}}}^{0}
$$

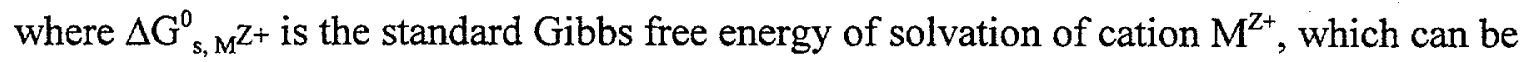
calculated from conventional Born solvation coefficients [4].

The terms of $\Delta \mathrm{G}_{\mathrm{n}, \mathrm{M}}^{\mathrm{Z}+}$ and $r_{\mathrm{M}} \mathrm{z}+$ are known for free metal cations. The coefficients

of $a_{\mathrm{MX}}, b_{\mathrm{MX}}$, and $\beta_{\mathrm{MX}}$ can be determined by fitting the equation to limited experimental data of $\Delta \mathrm{G}_{\mathrm{f}, \mathrm{MX}}^{\mathrm{i}}$ in an isostructural family of solids. The obtained equation can be then used to predict the unknown $\Delta \mathrm{G}_{\mathrm{f}, \mathrm{MX}}^{0}$ for other solids within the same family.

\section{PREDICTION OF GIBBS FREE ENERGIES OF FORMATION OF ACTINIDE PYROCHLORE MINERALS}

Since no $\Delta \mathrm{G}_{\mathrm{f}, \mathrm{MX}}^{0}$ data are currently available for pyrochlore phases, Equation (1) can not be directly applied to these mineral phases. Instead, the coefficients in Equation (1) for pyrochlore phases are extrapolated from zirconolite data. For the isostructural family of $\mathrm{CaMTi}_{2} \mathrm{O}_{7}$ with a zirconolite structure, the Gibbs free energies of formation have been determined for the $\mathrm{CaZrTi}_{2} \mathrm{O}_{7}$ and $\mathrm{CaHfTi}_{2} \mathrm{O}_{7}$ phases $[8,9]$. In order to apply the above linear free energy relationship, the coefficient $a_{\mathrm{Mx}}$ or $\beta_{\mathrm{Mx}}$ needs to be estimated independently. The coefficient $\beta_{\mathrm{Mx}}$ is related to the effect of nearest neighbors or coordination number $(\mathrm{CN})$ of cation [4]. In polymorphs, a structure family with a small $\mathrm{CN}$ (e.g., $\mathrm{CN}=6$ in calcite structure family) has a higher value of $\beta_{\mathrm{MX}}$ than a family with a big $\mathrm{CN}$ (e.g., $\mathrm{CN}=9$ in aragonite structure family) does [4]. The value of $\beta_{\mathrm{MX}}$ for the $\mathrm{MO}_{2}$ family with a fluorite structure ( $\mathrm{CN}$ of $\mathrm{M}$ atom is 8$)$ is $32.0(\mathrm{kcal} / \mathrm{mole} \AA$ ) (Table 1$)$. The value of $\beta_{\mathrm{MX}}$ for the $\mathrm{MSiO}_{4}$ family with a zircon structure ( $\mathrm{CN}$ of $\mathrm{M}$ atom is 7) is 64.83 (kcal/mole $\AA$ ) [5. 6]. As a first-order approximation, we use $\beta_{\mathrm{MX}}$ value of 65 $(\mathrm{kcal} / \mathrm{mole} \AA)$ for the zirconolite family $(\mathrm{CN}=7)$. Using the Gibbs free energies of 
formation of $\mathrm{CaZrTi}_{2} \mathrm{O}_{7}$ and $\mathrm{CaHfTi}_{2} \mathrm{O}_{7}$ phases $[8,9]$, the coefficients of $a_{\mathrm{Mx}}$ and $b_{\mathrm{MX}}$ for zirconolite family can be calculated to be 0.5717 and $-1024.06 \mathrm{kcal} / \mathrm{mole}$, respectively.

Based on the results from other oxide and silicate families, the coefficient $a_{\mathrm{Mx}}$ seems only related to the stoichiometry of solids [4]. Values of the coefficient $a_{\mathrm{MX}}$ are very close for all polymorphs [4]. Therefore, the $a_{\mathrm{Mx}}$ value of 0.5717 is applied to pyrochlore phases. Similarly, we apply the $\beta_{\mathrm{MvX}}$ value of $32(\mathrm{kcal} / \mathrm{mole} \AA)$ obtained for the $\mathrm{MO}_{2}$ family with fluorite structure $(\mathrm{CN}=8)$ to the pyrochlore family. The main difference between zirconolite and pyrochlore with the same stoichiometry of $\mathrm{CaMTi}_{2} \mathrm{O}_{7}$ is the coordination number of $\mathrm{Zr}$. The coordination number of $\mathrm{M}$ atoms in the zirconolite structure and pyrochlore structure are 7 and 8 , respectively. The difference in Gibbs free energies between calcite $\left(\mathrm{CaCO}_{3}\right)$ and aragonite polymorphs is about $0.2(\mathrm{kcal} / \mathrm{mole})$ [4]. The difference in Gibbs free energies between Al-Si ordered low-albite (CN of Na atom is 7) and $\mathrm{Al}-\mathrm{Si}$ disordered high-albite ( $\mathrm{CN}$ of $\mathrm{Na}$ atom is 9) polymorphs is about 2.0 ( $\mathrm{kcal} / \mathrm{mole}$ ) [10]. However, the contribution from Al-Si odering in tetrahedral sites that can be calculated from the Gibbs free energies of formation of Al-Si ordered microcline and $\mathrm{Al}-\mathrm{Si}$ disordered sanidine is about $1.6(\mathrm{kcal} / \mathrm{mole})$ [10]. Thus, the free energy contribution from the difference in coordination number of low-albite and high albite is about $0.4(\mathrm{kcal} / \mathrm{mole})$. Therefore, we postulate that the Gibbs free energy difference between the zirconolite and pyrochlore structures is within the range of $0.2-0.4$ $\mathrm{kcal} / \mathrm{mole}$. It is proposed here that the Gibbs free energy of formation for $\mathrm{Zr}$-pyrochlore $\left(\mathrm{CaZrTi}_{2} \mathrm{O}_{7}\right)$ is about $0.3(\mathrm{kcal} / \mathrm{mole})$ higher than that of $\mathrm{Zr}$-zirconolite $\left(\mathrm{CaZrTi}_{2} \mathrm{O}_{7}\right)$. The coefficient $b_{\mathrm{MvX}}$ for pyrochlore phases is thus $-997.67(\mathrm{kcal} / \mathrm{mole})$. The predicted standard Gibbs free energies of formation for other phases in the pyrochlore family with a stoichiometry of $\mathrm{CaM}^{4+} \mathrm{Ti}_{2} \mathrm{O}_{7}$ are listed in Table 1 .

\section{THERMODYNAMIC STABILITY OF PYROCHLORE MINERALS IN DEEP GEOLOGIC REPOSITORY ENVIRONMENTS}

Based on the predicted Gibbs free energies of formation of pyrochlore and Gibbs free energies of formation of perovskite and rutile [11], we can calculate the Gibbs free energy change of the following reaction $\left(\delta \Delta \mathrm{G}_{\mathrm{rxt}}\right)$ of the reaction at a room temperature:

$$
\mathrm{MO}_{2}+\underset{\text { perovskite }}{\mathrm{CaTiO}_{3}}+\underset{\text { rutile }}{\mathrm{TiO}_{2}}=\underset{\text { pyrochlore }}{\mathrm{CaMTi}_{2} \mathrm{O}_{7}}
$$

The calculated Gibbs free energy changes $\left(\delta \Delta \mathrm{G}_{\mathrm{rxt}}\right)$ are listed in Table 1 . The Cepyrochlore has been synthesized by sintering oxides of $\mathrm{CeO}_{2}, \mathrm{CaTiO}_{3}$, and $\mathrm{TiO}_{2}[12,13]$. As the annealing temperature decreases (from $1300^{\circ} \mathrm{C}$ to $1140^{\circ} \mathrm{C}$ ), the proportions of Ce-pyrochlore increases by consuming oxides of $\mathrm{CeO}_{2}$ and $\mathrm{CaTiO}_{3}$ phases [13]. This experimental observation is consistent with our prediction of the negative Gibbs free energy change across reaction (3) for Ce-pyrochlore. In contrast, Th-pyrochlore phase will be unstable with respect to $\mathrm{ThO}_{2}, \mathrm{CaTiO}_{3}$, and $\mathrm{TiO}_{2}$, To our knowledge, no 
successful synthesis of Th-pyrochlore phase has been reported. It can be seen from Table 1 that the Gibbs free energy change in reaction (3) for Pu-pyrochlore (3) is more negative than that of Ce-pyrochlore (Table 1), indicating that the synthesis of Pu-pyrochlore from oxides is thermodynamically feasible.

Table 1. Ionic radii, thermodynamic data for aqueous cations, and predicted standard Gibbs free energies of formation (kcal/mole) [5]

\begin{tabular}{|c|c|c|c|c|c|c|c|c|}
\hline $\mathrm{M}^{4+}$ & $\begin{array}{r}r_{\mathrm{M}^{4+}} \\
(\AA)\end{array}$ & $\Delta G_{s} M^{s+}$ & $\Delta \mathrm{G}_{\mathrm{f}} \mathrm{M}^{\mathrm{d+}}$ & $\Delta \mathrm{G}_{\mathrm{n}} \mathrm{M}^{4+}$ & $\begin{array}{c}\mathrm{MO}_{2} \\
\text { (Exper.) }\end{array}$ & $\begin{array}{c}\mathrm{MO}_{2} \\
\text { (Calculated) }\end{array}$ & 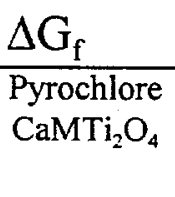 & $\frac{\delta \Delta G_{r x t}}{\text { Reaction }}$ \\
\hline $\mathrm{Zr}$ & 0.79 & -373.11 & -141.00 & 232.11 & -249.23 & -249.21 & -839.70 & -1.67 \\
\hline $\mathrm{Hf}$ & 0.78 & -374.41 & -156.80 & 217.61 & -260.09 & -259.24 & -848.30 & -0.24 \\
\hline $\mathrm{Ce}$ & 0.94 & -354.23 & -120.40 & 233.79 & -244.40 & -243.28 & -833.93 & -1.83 \\
\hline Th & 1.02 & -344.65 & -168.50 & 176.13 & -279.34 & -279.35 & -864.34 & 3.83 \\
\hline $\mathrm{U}$ & 0.97 & -350.60 & -124.40 & 226.20 & -246.62 & -247.40 & -837.31 & -1.09 \\
\hline $\mathrm{Np}$ & 0.95 & -353.02 & -120.20 & 232.82 & -244.22 & -243.61 & -834.17 & -1.74 \\
\hline $\mathrm{Pu}$ & 0.93 & -355.45 & -115.00 & 240.49 & -238.53 & -239.11 & -830.42 & -2.49 \\
\hline $\mathrm{Am}$ & 0.92 & -356.68 & -89.20 & 267.48 & -220.72 & -221.35 & -815.31 & -5.14 \\
\hline Po & 1.10 & -339.98 & 70.00 & 409.98 & & -121.39 & -729.36 & -11.54 \\
\hline
\end{tabular}

The negative Gibbs free energy change in reaction (3) predicted for Pu-pyrochlore implies that this mineral phase is stable with respect to $\mathrm{PuO}_{2}, \mathrm{CaTiO}_{3}$, and $\mathrm{TiO}_{2}$ at a room temperature. A reaction-path calculation using computer code EQ3/6 [14] shows that $\mathrm{PuO}_{2}$ and $\mathrm{TiO}_{2}$ are both stable in a Yucca Mountain environment. Considering that the Yucca Mountain repository is relatively oxic, we expect $\mathrm{PuO}_{2}$ to be stable in most deep repository environments. Therefore, out of three minerals in the left side of reaction (3), at least two of them are stable. The stability of $\mathrm{Pu}$-pyrochlore thus depends on the stability of perovskite $\left(\mathrm{CaTiO}_{3}\right)$.

The stability of perovskite $\left(\mathrm{CaTiO}_{3}\right)$ is controlled by the fugacity of $\mathrm{CO}_{2}$ and the activity of silica. In the presence of silica or $\mathrm{CO}_{2}$, perovskite $\left(\mathrm{CaTiO}_{3}\right)$ is unstable in a low temperature environment [15], because of the following reactions:

$$
\begin{aligned}
& \mathrm{CaTiO}_{3}+\mathrm{H}_{4} \mathrm{SiO}_{4}(\mathrm{aq})=\mathrm{CaTiSiO}_{5}+2 \mathrm{H}_{2} \mathrm{O} \quad \log \mathrm{K}=8.9 \\
& \text { perovskite sphene } \\
& \underset{\text { perovskite }}{\mathrm{CaTiO}_{3}}+\mathrm{CO}_{2}(\mathrm{~g})=\underset{\text { calcite }}{\mathrm{CaCO}_{3}}+\underset{\mathrm{TiO}_{2}}{\text { rutile }} \quad \log \mathrm{K}=8.5
\end{aligned}
$$

where $\mathrm{K}$ is the equilibrium constant of the reaction and is calculated using the data from [11]. However, in the absence of both silica and $\mathrm{CO}_{2}, \mathrm{CaTiO}_{3}$ will be stable in an aqueous solution, because the following reaction is thermodynamically not favorable: 
$\begin{aligned} & \mathrm{CaTiO}_{3} \\ & \text { perovskite }\end{aligned}+\mathrm{H}_{2} \mathrm{O}=\underset{\text { portlandite }}{\mathrm{Ca}(\mathrm{OH})_{2}}+\mathrm{TiO}_{2} \quad \log \mathrm{K}=-4.3$

Consequently, Pu-pyrochlore will also become stable. Based on this argument, we suggest that a repository in a salt formation be an ideal environment for disposal of high level, pyrochlore-based ceramic wastes. The stability of pyrochlore and perovskite in this environment can be further ensured by adding $\mathrm{CaO}$ as a backifll. $\mathrm{CaO}$ will sequester any carbonate originally present in groundwater through reaction:
$\mathrm{Ca}(\mathrm{OH})_{2}$
$+\mathrm{CO}_{2}=\mathrm{CaCO}_{3}$
$\log \mathrm{K}=12.8$
Bruicte
calcite
(hydrated $\mathrm{CaO}$ )

and, therefore, will keep both pyrochlore and perovskite minerals thermodynamically stable in the repository.

Even for a repository located in a silicate rock, depending on groundwater flow rates, silica and carbonate may become depleted in the near field due to chemical reactions, and then pyrochlore and perovskite may be still able to approach a stable state. In short, to assess the performance of pyrochlore ceramic waste, silica and carbonate concentrations in the near field must be carefully evaluated.

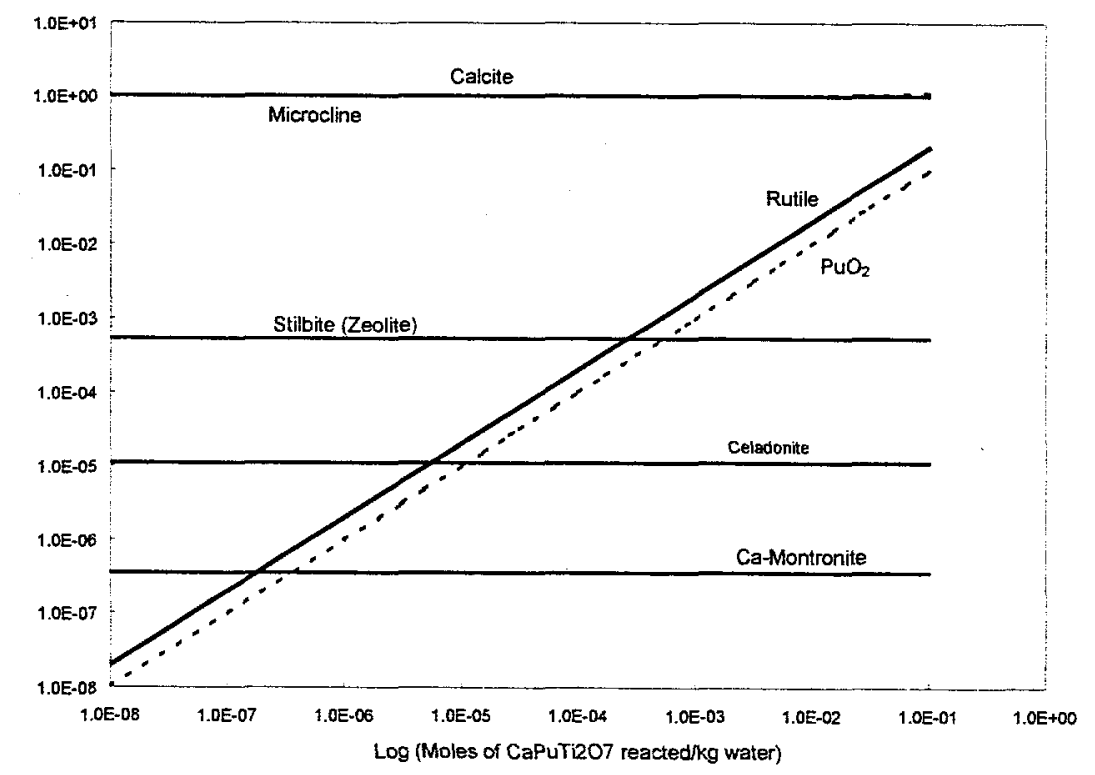

Figure 1. Reaction path calculation for Pu-pyrochlore dissolution in a Yucca Mountain repository environment. The fugacities of oxygen and carbon dioxide are maintained at $3.3 \times 10^{-30}$ atm and $5.0 \times 10^{-3} \mathrm{~atm}$, respectively. 


\section{CONCLUSIONS}

A linear free energy relationship has been used to predict the Gibbs free energies of formation of pyrochlore phases $\left(\mathrm{CaMTi}_{2} \mathrm{O}_{7}\right)$. The coefficients in Equation (1) for pyrochlore phases are estimated to be: $a_{\mathrm{MX}}=0.5717, b_{\mathrm{MX}}=-997.67(\mathrm{kcal} / \mathrm{mole})$, and $\beta_{\mathrm{MX}}$ $=32(\mathrm{kcal} / \mathrm{mole} \AA)$. The Pu-pyrochlore phase is predicted to be stable with respect to $\mathrm{PuO}_{2}, \mathrm{CaTiO}_{3}$, and $\mathrm{TiO}_{2}$ at room temperatures. Pu-pyrochlore is expected to be stable in a geologic repository where silica and carbonate components are absent or limited. A repository in a salt formation is proposed as an ideal environment for disposal of high level, pyrochlore-based ceramic wastes. In such environment, adding $\mathrm{CaO}$ as a backfill will make pyrochlore minerals thermodynamically stable and therefore effectively prevent actinide release from these mineral phases.

\section{ACKNOWLEDGMENTS}

Sandia is a multiprogram operated by Sandia Corporation, a Lockheed Martin Company, for the United States Department of Energy under Contract DE-AC0494AL8500.

\section{REFERENCES}

1. R.G. Dosch, T.J. Headley, C.J. Northrup, and P.F. Hlava, Sandia National Laboratories, Albuquerque, NM, Report SAND82-2980 (1983).

2. A.E. Ringwood, S.E. Kesson, K.D. Reeve, D.M. Levins, and E.J. Ramm, Synroc, In Radioactive Waste Forms for the Future, edited by W. Lutze and R.C. Ewing, (NorthHolland, Amsterdam, 1988), p. 233.

3. E.R. Vance, MRS Bulletin, XIX (12), 28 (1994).

4. D.A. Sverjensky, Nature, 358, 310 (1992).

5. H. Xu and Y. Wang, J. Nucl. Mater., 275, 216 (1999).

6. H. Xu, Y. Wang, and L. Barton, J. Nucl. Mater., 273, 343 (1999).

7. H. Xu and Y. Wang, Radiochim. Acta, 87, 37 (1999).

8. R.L. Putnam, A. Navrotsky, B.F. Woodfield, J.L. Shapiro, R. Stevens, and J. BoerioGoates, In Scientific Basis for Nuclear Waste Management XXII, Boston (Nov. 30Dec. 4, 1998) edited by D.J. Wronkiewicz and J.H. Lee (Mater. Res. Soc. Symp. Proc., 556, Warrendale, PA, 1999) pp. 11-18.

9. R.L. Putnam, A. Navrotsky, B.F. Woodfield, J. Boerio-Goates, and J.L. Shapiro, J. Chem. Thermodynamics, 31, 229 (1999).

10. R.G. Berman, J. Petrology, 29, 445 (1988).

11. R. Robie and B.S. Hemingway, Thermodynamic Properties of Minerals and Related Substances at $298.15 \mathrm{~K}$ and 1 Bar (105 Pascals) Pressure and at Higher Temperatures, Geological Survey Bulletin No. 2131 (U.S. Geological Survey, Denver, CO) 461 pp. (1992).

12. $\mathrm{H}$. Xu and $\mathrm{Y}$. Wang, In Radioactive Waste Management and Environmental Remediation-ICEM99, in press (1999).

13. R.L. Putnam (personal communication) (1999). 
14. T.J. Wolery, EQ3/6, A Software Package for Geochemical Modeling of Aqueous Systems (Version 7.0), Lawrence Livermore National Laboratory, Livermore, CA, Report UCRL-MA-110662 Pt. 1 (1992).

15. H.W. Nesbitt, G.M. Bancroft, W.S. Fyfe, S.N. Karkhanis, and A. Nishijima, Nature, 289, 358-362 (1981). 